\title{
МЕТОДИ ОЦІНЮВАННЯ БОЛЮ В ДИТЯЧОМУ ВІЦІ
}

\author{
С. В. Іванова, Н. Б. Галіяш \\ Запорізький обласний спеціалізований будинок дитини “Сонечко» \\ ДВНЗ «Тернопільський державний медичний університет \\ імені І. Я. Горбачевського МОЗ України"
}

У статті проаналізовано проблемні питання фізіології та оцінювання стійкого болю у дітей, а також можливість впровадження найпоширеніших інструментів для вимірювання болю в дитячому віці.

\section{METHODS OF PAIN ASSESSMENT IN CHILDHOOD}

\author{
S. V. Ivanova, N. B. Haliyash \\ Zaporizhzhia Regional Specialized Children's Home «Sonechko» \\ I. Horbachevsky Ternopil State Medical University
}

The article analyzes the problematic issues of physiology and assessment of persistent pain in children, as well as the possibility of implementation of the most common tools for pain evaluation in childhood.

Вступ. Особливо важливою проблемою в охороні здоров'я багатьох країн світу $є$ діагностика та контроль болю у дітей. 3 кожним роком розуміння дитячого болю поглиблюється, розширюються можливості його лікування. Недостатня діагностика і непродумана терапія можуть призвести до несприятливих фізіологічних ефектів. Головним завданням лікаря $\epsilon$ оцінка типу та характеру болю. Оцінку болю проводять, беручи до уваги анамнез (попередній больовий досвід дитини); больові відчуття; ставлення до болю та хвороби; клініка та визначення причини болю; частота больових нападів; фактори можливих ризиків. Для вимірювання болю використовують найпоширеніші інструменти - шкали інтенсивності болю.

Основна частина. Біль - це фізичне або душевне страждання. Міжнародна асоціація вивчення болю (International Association for the Study of Pain, IASP) визначає біль як «неприємний чуттєвий та емоційний досвід, пов'язаний з актуальним чи потенційним пошкодженням тканини» [1]. Біль має різні складові: афективна складова (емоції), когнітивна складова (переконання, культурне та духовне ставлення до болю, контроль болю), фізіологічна складова (передача неприємних стимуліву мозок). Розрізняють два основні види болю - ноцицептивний (поділяється

(c) С. В. Іванова, Н. Б. Галіяш, 2017 на соматичний та вісцеральний ) та невропатичний (периферійний та центральний).

Стійкий біль - це будь-який довготривалий біль, пов'язаний з соматичними захворюваннями [2, 3].

Ноцицептивний біль виникає, коли ураження тканини активує особливі рецептори болю.

Соматичний біль виникає внаслідок активації ноцицепторів у покривних тканинах (шкіра, слизова оболонка рота, ніс, уретра, анус).

Вісцеральний біль виникає внаслідок активації ноцицепторів у вісцеральних органах (внутрішніх органах, розташованих у порожнині тіла: органи грудної та черевної порожнини). Вісцеральний біль може виникати через інфекцію, здуття від рідини чи газу, розтягнення або стиснення, від щільних пухлин.

Невропатичний біль зумовлений структурним ушкодженням та дисфункцією нервових клітин у периферійній або центральній нервовій системі.

Периферійний невропатичний біль у дітей спричиняється ураженням нерва, ущемленням нерва або зовнішнім стисненням будь-яким об'ємним ураженням (пухлиною або абсцесом); ураженням нерва внаслідок ВІЛ або токсичних ефектів антиретровірусної терапії; доброякісними пухлинами нерва (нейрофіброма або рубцева неврома після травми чи операції). 
Центральний невропатичний біль виникає внаслідок пошкодження спинного мозку.

Змішаний біль може виникати при травмах, які пошкоджують тканини й нерви, опіках, раку [2, 3].

Ретельний медичний огляд має важливе значення, і кожне місце болю слід уважно оцінити. Під час обстеження лікар повинен уважно стежити за будьякими проявами реакції дитини (вираз обличчя, ригідність черевної порожнини, мимовільні згинання, словесні сигнали, що можуть свідчити про біль. Будь-які викликані болем зміни в нормальному функціональному статусі мають бути оціненими.

Вираження болю залежить від віку дитини, когнітивного розвитку та соціокультурного контексту.

У дітей, які не можуть говорити, повідомлення про біль залежить від батьків та/або оглядальників. Батьки знають типову поведінкову реакцію своєї дитини на біль, це можна долучати до оцінки болю. Спостереження за поведінкою, пов'язаною з болем, $\epsilon$ прийнятним підходом до оцінки болю в дітей віком до трьох років і в дітей із обмеженими вербальними та когнітивними здібностями.

Для оцінки й документування болюу дітей використовують різні інструменти вимірювання болю. Були також розроблені інструменти для вирішення питання оцінки болю в дітей, котрі не вміють говорити, та дітей із когнітивними порушеннями. Оцінка болю завжди можлива певною мірою, навіть у критично хворої дитини або дитини з когнітивними порушеннями.

У процесі оцінювання болю беруть участь дитина, батьки або піклувальники та медпрацівники. Те, як дитина сприймає біль, є результатом біологічних, психологічних, соціальних, культурнихта духовних чинників. Оцінювання болю вимагає комплексного підходу [3].

Рейтингова шкала оцінки болю за виразом обличчя Вонга-Бейкера для дітей старше 3 років (Wong-Baker Faces Pain Scale for Children 3 Years or Older (D. L. Wong, C. M. Baker, 1988)).

Шкала Вонга-Бейкера створена для оцінки інтенсивності болю у дітей. Вона включає картинки зі зображенням обличчя -усміхненого, що означає відсутність болю (0 балів із 5), спотвореного гримасою плачу особи, що означає найсильніший за інтенсивністю біль (5 балів із 5). Ця шкала зручна для застосування у дітей та у пацієнтів з утрудненням вербальної комунікації. Шкала ВонгаБейкера також має тісний взаємозв'язок із показниками візуальної аналогової шкали і шкали болю за виразом обличчя (табл. 1, рис.).

Таблиця 1. Дитяча шкала для оцінки болю за виразом обличчя Вонга-Бейкера для дітей старше 3 років (Wong-Baker Faces Pain Scale for Children 3 Years or Older (D. L. Wong, C. M. Baker, 1988))

\begin{tabular}{|l|l|c|}
\hline \multicolumn{1}{|c|}{ Обличчя } & \multicolumn{1}{|c|}{ Опис } & Бали \\
\hline Усміхнене & Щасливий, болю немає & 0 \\
\hline Легка посмішка & Незначна хворобливість & 1 \\
\hline Нейтральне & Легкий біль & 2 \\
\hline Нахмурені злегка брови & Біль середньої тяжкості & 3 \\
\hline Брови сильно нахмурені & Сильний біль & 4 \\
\hline Плаче, відчуває себе абсолютно нещасним & Надмірний біль, що тільки можна уявити & 5 \\
\hline
\end{tabular}

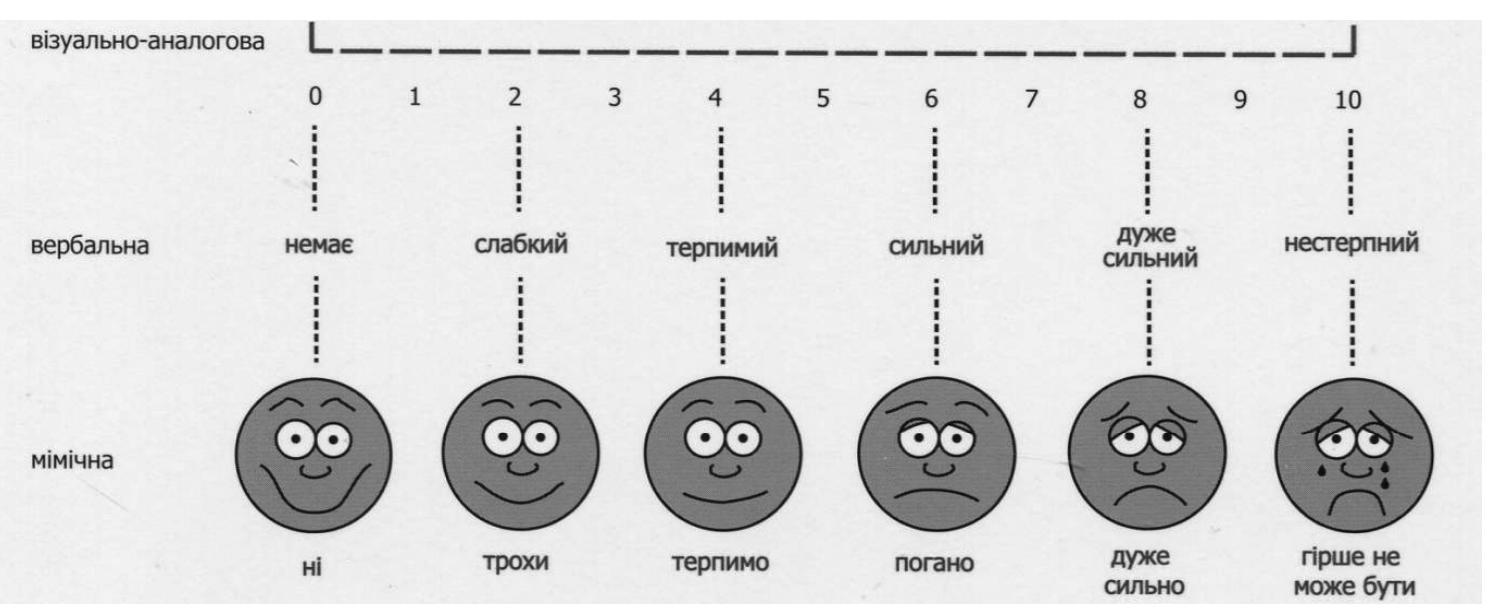

Рис. Шкала оцінки інтенсивності болю. 
Шкала включає п'ять критеріїв: плач, вираз обличчя, положення тіла, положення ніг, рухове занепокоєння. Всі параметри оцінюють в діапазоні від 0 до 5 балів (табл. 2).

При обстеженні дитини оцінюють 5 параметрів. Час огляду дитини не повинен перевищувати 15 с, навіть якщо найближчим часом після цього поведінка дитини змінюється.

Для оцінки болю у дітей віком з 6 місяців до 7 років рекомендують використовувати, особливо у тих, які не вміють говорити або мають порушення мовної спроможності, шкалу FLACC (табл. 3).

\section{Таблиця 2. Дитяча шкала для оцінки ступеня болю KUSS (Kindliche unbehagens-und Schmerzskala}

(KUSS) (W. Büttner et al., 1998))

\begin{tabular}{|c|c|c|}
\hline Параметри & Характеристика & Бали \\
\hline \multirow{3}{*}{ Плач } & Відсутній & 0 \\
\cline { 2 - 3 } & Стогін, хникання & 1 \\
\cline { 2 - 3 } & Жалібний крик & 2 \\
\hline \multirow{2}{*}{ Вираз обличчя } & Розслаблено, посміхається & 1 \\
\cline { 2 - 3 } & Рот скривлений & 2 \\
\cline { 2 - 3 } & Гримаса & 0 \\
\hline \multirow{2}{*}{ Положення тіла } & Нейтральне & 1 \\
\cline { 2 - 3 } & Вимушене & 2 \\
\cline { 2 - 3 } & Витягується, звивається & 0 \\
\hline \multirow{2}{*}{ Положення ніг } & Нейтральне & 1 \\
\cline { 2 - 3 } & Борсається, штовхається & 2 \\
\cline { 2 - 3 } & Підтягує до тіла & 0 \\
\hline Рухове занепокоєння & Відсутнє & 1 \\
\cline { 2 - 3 } & Незначне & 2 \\
\cline { 2 - 3 } & Неспокійний & \\
\hline
\end{tabular}

Таблиця 3. Оцінка болю у дітей, які не вміють говорити або з порушеннями мовної спроможності (з 6 місяців до 7 років) (шкала FLACC)

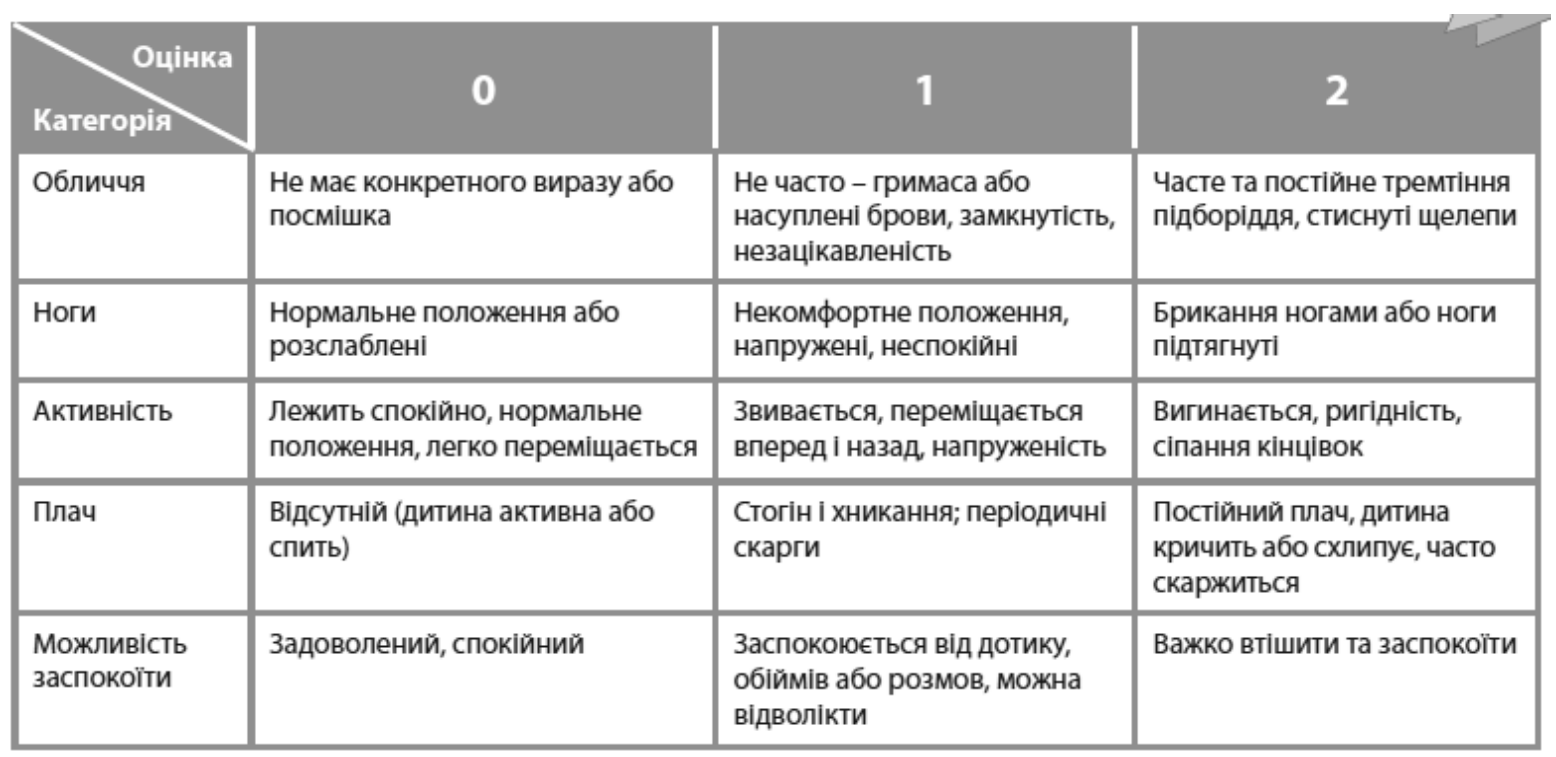

Інтерпретація: максимальна оцінка - 10 балів, сума більше 3 означає наявність болю.

Висновки. Для забезпечення якісного лікування необхідно навчати медичних працівників важливості оцінки болю. Вони повинні навчитися працювати з батьками/оглядальниками. Оцінка болю $\epsilon$ обов'язковою частиною ведення болю, подібно до оцінки показників життєдіяльності у веденні розладів, що уражають інші функції системи.

За останні 10 років у Нідерландах посилюється увага як до оцінки ступеня болю у дітей, так і до його усунення. Зазвичай для населення Нідерландів спо- 
соби оцінки болю адаптовані до розроблених у США і Великій Британії. На сьогодні в різних установах Нідерландів здійснюють інтегровані проекти 3 розробки методів вимірювання ступеня болю у дітей від народження до 3 років. Також розпочато розробку методів реєстрації якості життя дитини з хронічним болем. Застосовуючи наявні методи і розробляючи нові, необхідно пам'ятати про те, що багато способів

\section{СПИСОК ЛІТЕРАТУРИ}

1. Настанови ВООЗ щодо фармакологічного лікування стійкого болю в дітей із медичними захворюваннями / за заг. ред. Л. І. Андріїшин та О. П. Брацюнь ; переклад 3 англійської С. Дьоми. - К. : ТОВ «Видавничий дім «Калита», 2016. - 168 с.

2. Інформаційний бюлетень № 3. Паліативна допомога / Л. Брацюнь, К. Шаповал, Л. Василенко. - С. 4-6. можна реалізувати в рамках дослідження, але вони часто потребують занадто великих витрат часу і праці, через це неможливе їх рутинне застосування в клінічній практиці. При розробці нових методів необхідно більшою мірою враховувати те, що оцінювати ступінь болю доводиться в повсякденномужитті: будинку, в школі та в лікарні.

3. Стійкий біль в дітей. - 2011. - С. 6-8.

4. Принципи лікування стійкого болю у дітей з соматичними захворюваннями : набір карток. - К. : ТОВ «Видавничий дім «Калита», 2016. - 12 с.

Отримано 05.10.17 